\title{
Determination of protein of edible insects
}

\section{Determinación de proteína de insectos comestibles}

\author{
GONZÁLEZ-AGUILAR, Delia†*, GALVÁN-LOZANO, Diana, PACHECO-GALLARDO, Carlos and \\ CABRERA-DÍAZ, Elisa
}

Centro Universitario de Ciencias Biológicas y Agropecuarias. Camino Ing. Ramón Padilla Sánchez. No. 2100, La Venta del Astillero, Zapopan, Jalisco. C.P. 45510

ID $1^{\text {st }}$ Author: Delia, González-Aguilar / ORC ID: 0000-0003-1413-2330

ID $1^{\text {st }}$ Coauthor: Diana, Galván-Lozano / ORC ID: 0000-0002-7720-5819

ID $2^{\text {nd }}$ Coauthor: Carlos, Pacheco-Gallardo / ORC ID: 0000-0002-5851-4616

ID $3^{\text {rd }}$ Coauthor: Elisa, Cabrera-Díaz / ORC ID: 0000-0002-1970-2104

DOI: $10.35429 / E J R N .2019 .9 .5 .12 .16$

Received June 28, 2019; Accepted December 22, 2019

\begin{abstract}
Mexico is a country with a wide variety of edible insects. Because of its high protein intake, insect consumption is proposed as a solution to hunger. However, studies on nutritional value are necessary.The objective of this work was the determination of chapulin protein. In this study, 14 chapulin (Sphenarium purpuarascens) samples collected in Guadalajara from Oaxaca and Morelos were analyzed and processed according to the Weende proximate analysis methodology that includes the Kjeldahl procedure for protein determination. The results on fresh weight basis were: water $22.68 \%$, dry matter $77.32 \%$, ashes $12.8 \%$, fat $6.78 \%$, fiber $3.38 \%$, protein $33.15 \%$ and nitrogen free extract $21.21 \%$. Protein digestibility was $91.21 \%$. Because of the protein content, chapulin flour can be used as a protein ingredient in other food products.
\end{abstract}

Insects, Nutritional value, Protein

\begin{abstract}
Resumen
México es un país que cuenta con una gran variedad de insectos comestibles. Debido a su alto aporte proteico, el consumo de insectos se propone como solución del hambre. El objetivo de este trabajo fue la determinación de proteína del insectos, chapulín (Sphenarium purpuarascens). Se analizaron 14 muestras de chapulín recolectados en Guadalajara, Jal. Procedentes de Oaxaca y Morelos, y se procesaron de acuerdo a la metodología de los análisis proximales Weende que incluye el procedimiento de Kjeldahl para determinación de proteína. Los resultados en base húmeda $(\mathrm{BH})$ obtenidos fueron: Humedad 22.68\%, Materia seca $77.32 \%$, cenizas $12.8 \%$, grasa cruda $6.78 \%$, fibra cruda $3.38 \%$, proteína cruda $33.15 \%$ y extracto libre de nitrógeno (ELN) 21.21\%. La digestibilidad proteica fue de $91.21 \%$. Por el contenido de proteína, la harina de chapulín, se podría utilizar como ingrediente proteico en productos alimenticios.
\end{abstract}

\section{Insectos, Valor nutricional, Proteína}

Citation: GONZÁLEZ-AGUILAR, Delia, GALVÁN-LOZANO, Diana, PACHECO-GALLARDO, Carlos and CABRERADÍAZ, Elisa. Determination of protein of edible insects. ECORFAN Journal-Republic of Nicaragua. 2019. 5-9: 12-16

\footnotetext{
$\dagger$ Researcher contributing as first author
} 


\section{Introduction}

The supply of animal protein to a constantly increasing population represents an important challenge worldwide. Therefore, different solutions have been proposed, including encouraging the consumption of insects that are high in protein. Mexico is a country that has a wide variety of edible insects. Due to its high protein intake, insect consumption is proposed as a solution to hunger. However, studies on nutritional value are necessary. Currently, the consumption of insects, known as entomophagy, is practiced by more than 2,000 million people mainly in the regions of Asia, Africa and Latin America.

In the world there are more than 1,900 species of insects that are consumed by humans, among which are crickets, grasshoppers, escamoles, beetles, chicatanas, etc. (García V., 2018; Van Huis et al., 2013). In Mexico approximately 200 species are consumed, such as chapulines or crickets, maguey worms, escamoles (known as Mexican caviar and precious since pre-Hispanic times), the acociles and jumiles (Badui, 2015).

This has environmental, health and social benefits, such as high efficiency of food conversion, emit less greenhouse gases and require less land and water for their upbringing (Van Huis et al., 2013). Entomophageal practice is considered a viable food option by 2050 , in which it is estimated that there will be 9,000 million inhabitants (Badui, 2015). However, in some countries such as the United States and Canada they present a rejection towards their consumption (García V., 2018).

Currently in Mexico there are several communities that have in their diet the consumption of insects, Oaxaca being the largest consumer, followed by states such as Guerrero, Morelos, Hidalgo, Chiapas, Veracruz and the State of Mexico, and with less in Campeche, Tabasco , Puebla, Querétaro, Guanajuato, Jalisco and Michoacán. Edible insects are a good source of protein, fat, unsaturated fatty acids, minerals of great importance such as iron and zinc, and vitamins such as thiamine and riboflavin (DeFoliart, 1997). To know the nutritional quality of insects it is necessary to determine the amount of protein and true moisture, fiber and raw fat, ashes, nitrogen-free extract, carbohydrates.
On the other hand, it is also necessary to know the amount of minerals such as magnesium, potassium, sodium, iron and zinc. The amount of protein in insects varies depending on the species and whether it is terrestrial or aquatic, among other factors. Most species have a proportion ranging from $55 \%$ to $70 \%$. They are also rich in essential amino acids (Ramos E. 2007).

In Mexico, among the most consumed insects are the chapulines. They contain between 70 and $77 \%$ of protein, more than $50 \%$ of beef (Viesca G., 2009) and 62\% of total protein and of this $89 \%$ is digestible (Ramos, E., 1989, Ramos, E. and Pino M. 1981). Since the consumption of chapulin is common in Mexico, studies on its quality and safety are necessary. The objective of the present investigation was to determine the protein value of Chapulin (Sphenarium purpurascencs).

\section{Methodology}

In the present study, 14 chapulin samples (Sphenarium purpurascencs) collected in Guadalajara, Jal., From the states of Oaxaca and Morelos were analyzed. Insects were obtained from suppliers with fixed establishments. They were transported in plastic bags labeled to the Laboratory of Food Physicochemistry of the Department of Public Health of the University Center of Biological and Agricultural Sciences of the University of Guadalajara where they were processed according to the methodology of Weende proximal analyzes that includes the Kjeldahl procedure for protein determination. The analyzes were performed in duplicate and the average values were reported. The determinations that were made were: moisture and dry matter, ashes, ethereal extract, fiber and crude protein, nitrogen-free extract (ELN) and protein digestibility. (Helrich, 1990).

\section{Determination of moisture and dry matter}

The moisture determination is based on the evaporation of water. In aluminum trays the chapulín samples were placed and left in a bacteriological oven at a temperature of $100{ }^{\circ} \mathrm{C}$ for 18 hours, then the whole sample was pulverized in a mill. $5 \mathrm{~g}$ of each sample was taken and passed to the drying bell for 20 minutes and the rest was reserved for the following determinations. 
By weight difference, initial and final, the amount of moisture in the sample was calculated according to the following formula:

$\%$ dry matter $=($ residue weight $) /($ sample weight $) \times 100$

$\%$ humidity $=100-\%$ dry matter

\section{Ash Determination}

Ashes is the inorganic portion that is obtained by calcining the food at temperatures between 550$600^{\circ} \mathrm{C}$. In a crucible, $2 \mathrm{~g}$ of sample were weighed, the muffle was calcined at a temperature between $550-600^{\circ} \mathrm{C}$ for 3 hours (Fig. 1 and 2). At the end of this time, the temperature was expected to drop to $100^{\circ} \mathrm{C}$ to pass the crucible to the drying bell for 20 minutes and then the residue was weighed. To calculate the amount of ashes the following formula was used:

$\%$ ash $=($ residue weight $) /($ sample weight $) \times 100$

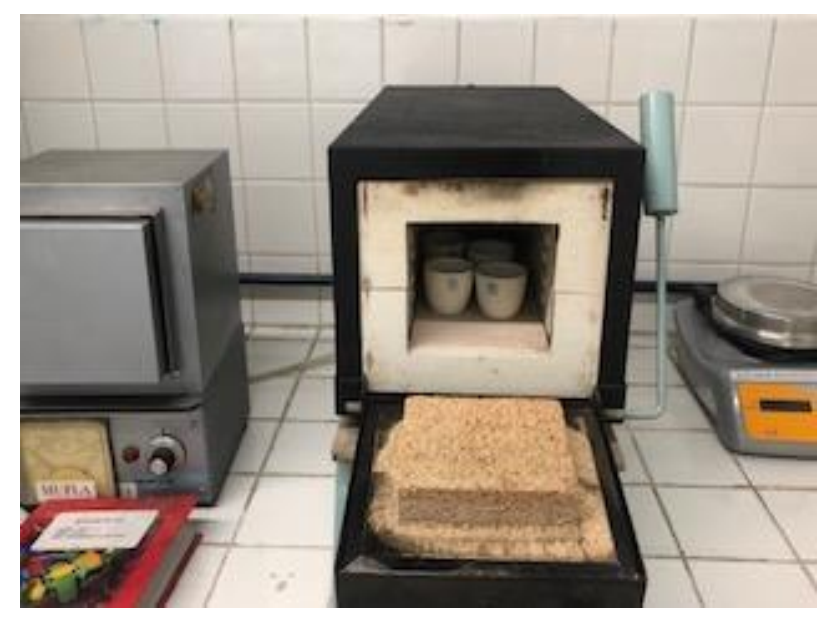

Figure 1 Determination of ashes

Source: Self Made

\section{Crude protein determination}

The basis of the method for determining crude protein was to quantify the total nitrogen and multiply it by a certain factor, the factor suggested for edible insects was used by Janssen, et al. (2017). The samples were processed according to the method of the Kjeldahl method which consisted of quantifying the total nitrogen and multiplying it by a certain factor, the factor suggested by Janssen, et al. (2017). Thus, the percentage of Crude Protein (total) of an organic sample can be obtained (Fig. 2).

The percentage of nitrogen was calculated as follows:
$\%$ nitrogen $=\mathrm{ml} \times$ normal HCL $(0.1) \times$ Meq. Nitrogen (0.014) / sample weight x 100

$\%$ crude protein $=\%$ nitrogen $x 5.6$

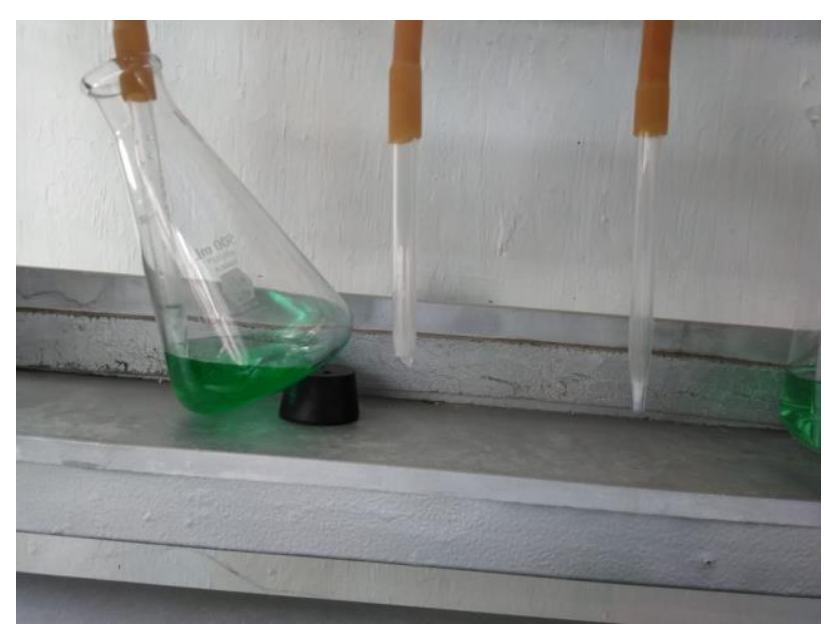

Figure 2 Determination of crude protein by the Kjedahl method

Source: Self Made

\section{Crude Fat Determination}

The Soxhlet method for determining crude fat (Fig. 3), quantifies the extractable substances in petroleum ether. $2 \mathrm{~g}$ of sample were weighed on filter paper, passed into a filter paper thimble and a glass for determination of crude fat. In the Soxhlet apparatus, extraction was carried out for 3 hours at a condensation rate of 5 to 6 drops per second. The ether was recovered and the residue was dried in a bacteriological oven at $100^{\circ} \mathrm{C}$ for 30 minutes. The samples were passed to the desiccator 20 minutes and the residue was weighed. The formula for calculating the percentage of raw fat is as follows:

$\%$ ethereal extract (G. C.) = (weight of the residue) / (weight of the sample) x 100

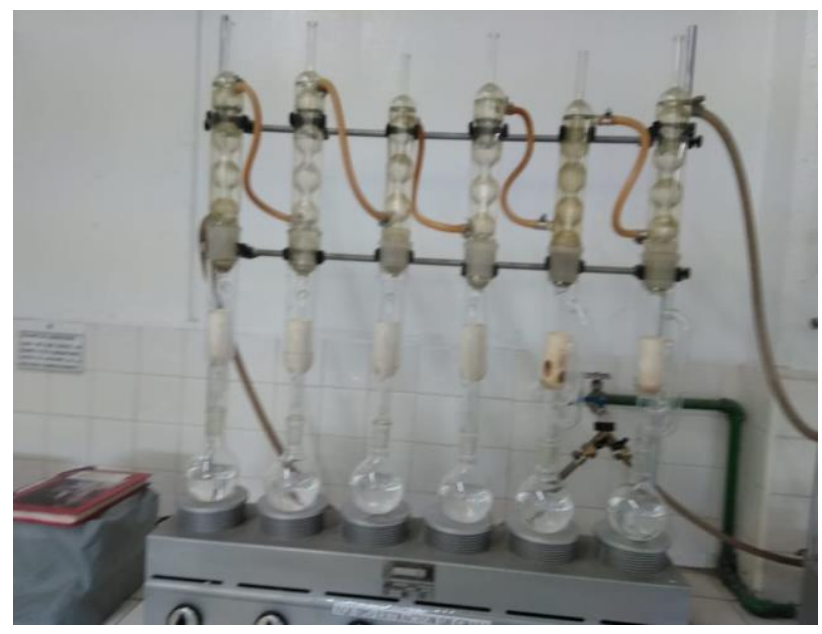

Figure 3 Soxhlet apparatus for determination of raw fat Source: Self Mad

GONZÁLEZ-AGUILAR, Delia, GALVÁN-LOZANO, Diana, PACHECO-GALLARDO, Carlos and CABRERA-DÍAZ, Elisa. Determination of protein of edible insects. ECORFAN Journal-Republic of Nicaragua. 2019 


\section{Crude Fiber Determination}

The method to determine the raw fiber was to calculate the loss by calcination of the residue of the acid and alkaline digestions of the sample (Fig. 4). For acid digestion, $0.5 \mathrm{~g}$ of each chapulin sample were weighed in previously degreased bags, transferred to a $600 \mathrm{ml}$ Berzelius glass, $200 \mathrm{ml}$ of $1.25 \%$ sulfuric acid was added, the vessel was placed in the digester and boiled for 55 minutes The same procedure is repeated for alkaline digestion, but with $200 \mathrm{ml}$ of $1.25 \%$ sodium hydroxide. The procedure was continued according to the method specification. The crude fiber was calculated with the following formula. $\%$ crude fiber $=($ crucible weight + dry fiber $)-$ (crucible weight + residue) - (bag weight $*$ correction factor [0.992]) / sample weight x 100

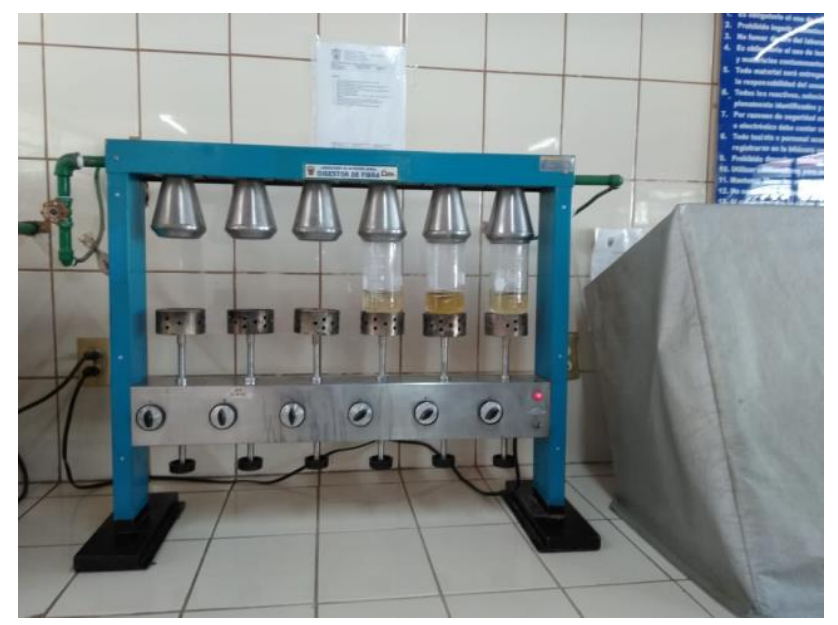

Figure 4 Determination of crude fiber

Source: Self Made

\section{Determination of Nitrogen Free Extract}

To determine the Nitrogen Free Extract, carbohydrates, sugars and starches were calculated by subtracting the difference from the other determinations made, according to the following formula:

$\%$ Nitrogen-free extract $=100-(\%$ humidity $+\%$ ash $+\%$ crude fat $+\%$ crude fiber $+\%$ crude protein).

\section{In vitro protein digestibility determination}

$3 \mathrm{~g}$ of sample were weighed and fat extraction was carried out, placed in a bacteriological oven at $100^{\circ} \mathrm{C}$ for 1.5 hours.
Two samples of $0.9859 \mathrm{~g}$ and $1.0777 \mathrm{~g}$ were weighed, each placed in a different Erlenmeyer flask labeled as sample 1 and sample 2, a solution of $3 \mathrm{ml} \mathrm{HCL}, 1 \mathrm{~g}$ pepsin, $50 \mathrm{ml}$ of double distilled water was added to each flask and a magnet They were placed on a hot plate with stirring at a temperature of $39^{\circ} \mathrm{C}$ for 18 hours, filtered with a medium filtration filter paper in a vacuum pump. For each sample, the crude protein determination is performed and digestibility is calculated as follows:

Average digestibility $=\%$ crude protein sample 1 $+\%$ crude protein sample $2 / 2$.

$\%$ digestibility $=\%$ crude protein $-\%$ average digestibility / average crude protein $\mathrm{x} 100$

\section{Results}

The results of the proximal analysis in wet base $(\mathrm{BH})$, which represents the value as it is in the chapulin samples can be observed in table No.1 and in table No. 2 the results in dry base (BS), that is, in samples without water.

\begin{tabular}{|l|r|}
\hline \multicolumn{1}{|c|}{ Analysis } & Value \% \\
\hline Dry material & 84.37 \\
\hline Humidity & 15.63 \\
\hline Crude protein & 35.80 \\
\hline Ethereal extract & 7.46 \\
\hline Ashes & 14.47 \\
\hline Raw fiber & 3.84 \\
\hline Nitrogen free extract & 22.81 \\
\hline
\end{tabular}

Table 1 Proximal chemical analysis Wet Base (B.H.) of Chapulín Sphenarium purpurascencs (grs / 100 g sample) Source: Own Elaboration

\begin{tabular}{|l|r|}
\hline \multicolumn{1}{|c|}{ Analysis } & Value \% \\
\hline Dry material & 100 \\
\hline Humidity & 0 \\
\hline Crude protein & 42.88 \\
\hline Ethereal extract & 8.36 \\
\hline Ashes & 17.96 \\
\hline Raw fiber & 4.61 \\
\hline Nitrogen free extract & 26.30 \\
\hline
\end{tabular}

Table 2 Proximal chemical analysis Base Seca (B. S.) of Chapulín Sphenarium purpurascencs (grs / 100 g sample) Source: Own Elaboration

On a wet basis, the protein digestibility of the samples was $91.21 \%$. 
This data is similar to $89.63 \%$ reported by Ramos, E. and Pino M. (1981) and published by Aragón, G. (2018), whose values varied between 80.22 and $85.48 \%$.

In this study, the amount of crude protein on a dry basis was $42.8 \%$ which was lower than the values between $52.13 \%$ and $75.3 \%$ published by Ramos, E. (1987).

\section{Acknowledgments}

We thank the staff of the Food Physicochemical Laboratory of the Department of Public Health of the University Center of Biological and Agricultural Sciences of the University of Guadalajara for the facilities granted to carry out the determinations of moisture and dry matter, ashes, ethereal extract, fiber and crude protein, nitrogen free extract (ELN) and protein digestibility.

\section{Conclusions}

Chapulín because of its high protein content can be an economic source and an important part in the diet of the human population.

\section{References}

Agustín Aragón-García, Diana Rosalba Rodríguez-Lima, José Manuel Pino-Moreno , Miguel Aragón-Sánchez, Sergio CarlosÁngeles, A. García-Pérez. (2018). Valor nutritivo de la harina del chapulín Sphenarium purpurascens Charpentier, 1845 (Orthoptera: Pyrgomorphidae) tostado y natural.. Entomología mexicana, 5, 106-112.

DeFoliart, G. (1997). An overview of the role of edible insects in preserving biodiversity. Ecology of food and nutrition, 36, 109-132.

Felipe Carlos Viesca González, Alejandro Tonatiuh Romero Contreras (2009). Entomophagy in Mexico. Some cultural aspects. El Periplo Sustentable. 16. 57-83

Gerardo Gregorio Garcia Valdez, Ruth María Zubillaga Alva (2018). Del Lenguaje Corporal, C. F. El impacto de la neofobia alimentaria y disponibilidad de los chapulines en los mercados extranjeros de los Estados Unidos de América y Canadá para su ingesta como un alimento del ser humano. Nuevas Habilidades Sociales. Investigaciones sociales de posgrado. 39.
Herlrich Kenneth (1990). Official Methods of Analysis of the Association of Official Analytical Chemists, 15 th. De. Arlington, USA. Janssen, R. H., Vincken, J. P., van den Broek, L. A., Fogliano, V., y Lakemond, C. M. (2017). Nitrogen-to-Protein Conversion Factors for Three Edible Insects: Tenebrio molitor, Alphitobius diaperinus, and Hermetia illucens. Journal of agricultural and food chemistry, 65(11), 2275-2278.

Ramos-Elorduy, J. y Viejo Montesinos, J. L. (2007) Los insectos como alimento humano: Breve ensayo sobre la entomofagia, con especial referencia a México. Boletín de la Real Sociedad Española de Historia Natural. Sección biológica, 102(1-4), 61-84.

Ramos Elorduy J. (1987). Los insectos como fuente de proteínas en el futuro. 2da. Edición, Noriega Limusa, México, D.F., pp. 19, 79, 106, $112,113$.

Ramos Elorduy J., Pino Moreno J.M. (1989). Los insectos comestibles en el México antiguo. Estudio etnoentomológico. AGT Editor, S.A, México, pp. 4, 50.

Ramos-Elorduy, J.; Pino M., J. M.; González M., O. (1981) Fol. Ent. Mex., 49, 141-154

Salvador Badui Dergal. (2015). La ciencia de los alimentos en la práctica. México: Pearson.

Van Huis, A., Van Itterbeeck, J., Klunder, H., Mertens, E., Halloran, A., Muir, G., \& Vantomme, P. (2013). Edible insects: future prospects for food and feed security (No. 171). Food and Agriculture Organization of the United Nations. 